\title{
PENENTUAN PROFIL KANDUNGAN KIMIA EKSTRAK ETANOL DAUN BINAHONG (Anredera scandens (L.) Moq.)
}

\author{
Samirana, P. O. ${ }^{1}$, Swastini D. A. ${ }^{1}$, Ardinata, I P. R. ${ }^{1}$, dan Suarka, I P. S. D. ${ }^{1}$ \\ ${ }^{1}$ Jurusan Farmasi Fakultas Matematika dan Ilmu Pengetahuan Alam Universitas Udayana \\ Korespondensi: Putu Oka Samirana \\ Jurusan Farmasi Fakultas Matematika dan Ilmu Pengetahuan Alam Universitas Udayana \\ Jalan Kampus Unud-Jimbaran, Jimbaran-Bali, Indonesia 80361 Telp/Fax: 0361-703837 \\ Email: oka_samirana@unud.ac.id
}

\begin{abstract}
ABSTRAK
Tanaman binahong (Anredera scandens (L.) Moq.) adalah salah satu tanaman yang secara empiris dapat memberikan aktivitas sebagai penyembuhan luka. Penelitian ini bertujuan sebagai standarisasi pada bahan baku obat tradisional yang selanjutnya dapat dikembangkan menjadi obat herbal terstandar atau bahkan fitofarmaka. Penentuan profil kromatografi kandungan fitokimia dari ekstrak Binahong (Anredera scandens (L.) perlu dilakukan untuk memastikan kualitas dari ekstrak Binahong (Anredera scandens (L.) Moq.) yang berkaitan dengan aktivitas yang diberikan. Penentuan profil kromatografi kandungan fitokimia dari ekstrak etanol daun binahong (Anredera scandens (L.) Moq.) dilakukan dengan metode KLT-Spektrofotodensitometri menggunakan fase gerak yang sesuai dengan golongan senyawa yang terkandung di dalamnya. Pada ekstrak etanol daun binahong (Anredera scandens (L.) Moq.) mengandung senyawa golongan flavonoid, saponin, triterpenoid dan tanin.
\end{abstract}

Keyword : profil kandungan kimia, daun binahong (Anredera scandens (L.) Moq.), spektrofotodensitometer

\section{PENDAHULUAN}

Binahong (Anredera scandens (L.) Moq.) adalah salah satu tanaman yang tergolong dalam famili Basellaceae dan secara empiris digunakan untuk mengobati radang usus, melancarkan dan menormalkan peredaran dan tekanan darah, sariawan, pusing, sakit perut, menurunkan panas tinggi, sembelit, sesak napas, maag, asam urat, keputihan, pembengkakan hati, daya tahan tubuh (Manoi, 2009).

Hasil uji bioaktivitas berdasarkan penelitian sebelumnya menunjukkan aktivitas ekstrak etanol daun binahong (Anredera scandens (L.) Moq.) sebagai antiluka bakar dan pengamatan secara histopatologi mampu meningkatkan granulasi jaringan dan kepadatan kolagen (Karismawan, 2013). Kemudian, daun binahong (A. scandes (L.) Moq.) juga memiliki aktivitas antiinflamasi pada dosis $500 \mathrm{mg} / \mathrm{kgBB}$ dan $1.000 \mathrm{mg} / \mathrm{kgBB}$ pada antibakteri gram positif (Streptococcus pyogenes) serta antibakteri gram negatif (Escherichia coli) dengan dosis $100 \mathrm{gram} / \mathrm{ml}$ (Feybriyanti, 2011; Fitria, 2009). Ekstrak etanol daun binahong (Anredera scandens (L.) Moq.) juga dilaporkan menunjukkan memiliki aktivitas sebagai antitukak padapengujian in vivo menggunakan tikus putih jantan galur Sprague Dawley dengan nilai $\mathrm{ED}_{50}$ sebesar $356 \mathrm{mg} / \mathrm{kgBB}$. Dalam ekstrak tersebut ditemukan kandungan kimia flavonoid, tanin, terpenoid dan saponin (Samirana, 2010).

KLT merupakan salah satu metode pada kromatografi planar. Pada KLT fase diamnya berupa lapisan pada permukaan bidang datar yang biasanya berupa aluminium, lempeng kaca, plastik. Fase gerak pada KLT akan bergerak sepanjang fase diam karena pengaruh kapiler dan polaritas pada pengembangan secara menaik (ascending), atau pengembangan secara menurun 
(descending) karena pengaruh gravitasi (Gandjar dan Rohman, 2007). Sedangkan spektrofotodensitometri adalah analisis mengunakan Instrumen densitometer terdiri dari sumber cahaya dalam rentang panjang gelombang 200-800 nm yaitu lampu deuterium (rentang spektra 200-400 nm), lampu tungsten (rentang spektra 400-800 nm) atau lampu merkuri bertekanan tinggi, slit (celah), monokromator untuk mengubah sinar polikromatis menjadi sinar monokromatis, filter flouresensi, pengganda foton dan rekorder (Gandjar dan Rohman, 2007)

Tujuan untuk menentukan profil kandungan kimia dalam suatu tanaman adalah untuk menentukan kandungan mana yang memiliki suatu aktivitas farmakologis. Hal tersebut digunakan sebagai standarisasi bahan baku yang selanjutnya dapat dikembangkan menjadiobat herbal terstandar atau bahkan fitofarmaka (Wijono, 2003). Pada penelitian ini, akan ditentukan profil kandungan kimia ekstrak etanol daun binahong (Anredera scandens (L.) Moq.) dengan metode KLT dengan pereaksi pendeteksi serta spektrofotodensitometer.

\section{BAHAN DAN METODE}

\subsection{Bahan}

Daun binahong (Hargobinangun, Yogyakarta); Etanol 70\% (Bratacem); silika gel G 60 F254 (Merck $\left.{ }^{\circledR}\right)$, asam oksalat $\left(\right.$ Merck $\left.^{\circledR}\right)$ dan asam borat $\left(\right.$ Merck $\left.^{\circledR}\right)$ berderajat pro analisis, pereaksi Dragendorff, Mayer, Hager dan Wagner, pelarut seperti aseton $\left(\right.$ Merck $\left.^{\circledR}\right)$, eter $\left(\right.$ Merck $\left.^{\circledR}\right)$, asam asetat anhidrat $\left(\operatorname{Merck}^{\circledR}\right), \mathrm{HCl}\left(\operatorname{Merck}^{\circledR}\right)$, etil asetat $\left(\operatorname{Merck}^{\circledR}\right)$, asam asetat $\left(\right.$ Merck $\left.^{\circledR}\right)$, kloroform $\left(\right.$ Merck $\left.^{\circledR}\right)$, metanol $\left(\right.$ Merck $\left.^{\circledR}\right)$ dan toluen $\left(\right.$ Merck $\left.^{\circledR}\right)$ masing-masing berderajat pro analisis serta asam formiat (Brataco) berderajat teknis. lempengan KLT silika G 60 F254 $\left(\right.$ Merck $\left.^{\circledR}\right)$, akuades, etil asetat $\left(\right.$ Merck $\left.^{\circledR}\right)$, asam asetat $\left(\right.$ Merck $\left.^{\circledR}\right)$, kloroform $\left(\right.$ Merck $\left.^{\circledR}\right)$, metanol $\left(\operatorname{Merck}^{\circledR}\right)$, toluen $\left(\operatorname{Merck}^{\circledR}\right)$, amonia $\left(\operatorname{Merck}^{\circledR}\right)$, dan dietil amin $\left(\right.$ Merck $\left.^{\circledR}\right)$ masing-masing berderajat pro analisis, dan asam formiat (Brataco) berderajat teknis.

\subsection{Alat}

Rotary evaporator $\left(\right.$ Eyela $\left.^{\circledR}\right)$; pipet kapiler, chamber (CAMAG), lampu UV (CAMAG) dan alat densitometer CAMAG TLC Scanner 4 dengan piranti lunak yang digunakan yaitu WIN-CATS 1.24.

\subsection{Prosedur Kerja}

\subsubsection{Preparasi Ekstrak Etanol Daun Binahong (A. scandens (L.) Moq.)}

Preparasi ekstrak diawali proses pengolahan Daun Binahong (A. scandens (L.) Moq.) menadi serbuk. Selanjutnya 500 gram serbuk kering Daun Binahong (A. scandens (L.) Moq.) diekstraksi dengan $5 \mathrm{~L}$ pelarut etanol 70\% menggunakan metode maserasi selama 24 jam. Selanjutnya dilakukan proses remaserasi sebanyak 2 kali. Maserat dipekatkan menggunakan alat rotary evaporator pada suhu $40^{\circ} \mathrm{C}$ untuk memeroleh ekstrak kental.

\subsubsection{Uji Fitokimia Ekstrak Etanol Daun Binahong (A. scandens (L.) Moq.) \\ Pada uji fitokimia dilakukan pemeriksaan kandungan flavonoid, saponin, triterpenoid dan tanin.}

a. Pembuatan larutan uji fitokimia

200 mg ekstrak kental dilarutkan dengan $20 \mathrm{~mL}$ metanol (Dewi dkk., 2013).

b. Pemeriksaan Flavonoid

$1 \mathrm{~mL}$ larutan uji diuapkan dahulu, lalu dibasahkan dengan aseton P. selanjutnya ditambahkan asam borat $\mathrm{P}$ dan serbuk asam oksalat P. Selanjutnya larutan dipanaskan dengan penangas air. selanjutnya larutan dicampur dengan $10 \mathrm{~mL}$ eter P. Reaksi positif kandungan flavonoid berupa flouresensi berwarna kuning intensif di bawah sinar UV 366 nm (Depkes RI, 1995).

\section{c. Pemeriksaan Saponin}

$10 \mathrm{~mL}$ larutan uji dalam tabung reaksi lalu dikocok vertikal selama 10 detik selanjutnya didiamkan selama 10 detik. Reaksi positif dari kandungan saponin dalam tanaman adalah pembentukan busa setinggi 1-10 cm selama 10 menit serta saat penambahan $\mathrm{HCl} 2 \mathrm{~N}$ sebanyak 1 tetes busa tersebut tidak hilang. (Depkes RI, 1995). 
d. Pemeriksaan Triterpenoid

$2 \mathrm{~mL}$ larutan uji diuapkan. Sampel kemudian dilarutkan dengan $0,5 \mathrm{~mL}$ kloroform, lalu ditambahkan asam asetat anhidrat $0,5 \mathrm{~mL}$ dan asam sulfat pekat sebanyak $2 \mathrm{~mL}$. Reaksi positif dari kandungan triterpenoid adalah terbentuknya cincin berwarna kecoklatan atau keunguan pada perbatasan larutan, sedangkan reaksi positif yang menunjukkan kandungan steroid adalah terbentuknya cincin biru kehijauan. Pemeriksaan steroid dan terpenoid ini dilakukan berdasarkan reaksi LiebermanBurchard. (Ciulei, 1984).

e. Pemeriksaan Tanin

5 mg ekstrak uji dilarutkan dengan 5 $\mathrm{mL}$ akuades kemudian ditambahkan beberapa tetes. larutan besi (III) klorida 5\%. Reaksi positif dari kandungan tanin adalah terbentuknya warna biru kehijauan (Vijayalakshmi and Ravindhran, 2012). Larutan ekstrak uji dibagi kedalam 2 bagian yaitu tabung $\mathrm{A}$, dan tabung $\mathrm{B}$ masing-masing sebanyak $2 \mathrm{~mL}$. Tabung A merupakan blanko sedangkan tabung $\mathrm{B}$ ditambahkan dengan larutan besi (III) klorida $10 \%$, reaksi positif dari kandungan polifenol adalah terbentuknya warna biru tua atau hijau gelap pada tabung B (Robinson, 1991).

\subsubsection{Penentuan profil kromatografi kandungan fitokimia ekstra etanol daun binahong (Anredera scandens (L.) Moq.)}

a. Pemilihan fase diam dan fase gerak

Fase diam berupa lempengan silika gel

G 60 F254 sedangkan fase gerak yang digunakan disesuaikan dengan kandungan kimia daun binahong (Anredera scandens (L.) Moq.) yang akan diidentifikasi. Kombinasi serta perbandingan dari fase gerak yang digunakan dapat dilihat pada tabel 1

Tabel 1 Sistem Pelarut yang Digunakan Untuk Profil KLT-Densitometer

\begin{tabular}{ll}
\hline Golongan Senyawa & \multicolumn{1}{c}{ Fase Gerak } \\
\hline Triterpenoid & Kloroform : Metanol (10: 1 \\
& $\mathrm{V} / \mathrm{V})$
\end{tabular}

\begin{tabular}{ll} 
& Etil Asetat : Asam Asetat : \\
Flavonoid & Asam Formiat : Air \\
& $(100: 11: 11: 26 \mathrm{v} / \mathrm{v})$ \\
Tanin & Etil Asetat : Toluen $(2: 98$ \\
& $\mathrm{v} / \mathrm{v})$ \\
Slopoform $:$ Metanol : Air \\
\\
Saponin & $(70: 30: 4 \mathrm{v} / \mathrm{v})$ \\
\hline
\end{tabular}

(Reich and Blatter, 2004)

b. Penentuan profil kandungan kimia ekstrak etanol daun binahong (Anredera scandens (L.) Moq.) dengan KLT-Densitometer

Chamber dijenuhkan terlebih dahulu selama 30 menit dengan kombinasi fase gerak berdasarkan tabel 2.1. sebelun ditotolkan ekstrak kental daun binahong (Anredera scandens (L.) Moq.) terlebih dahulu dilarutkan menggunakan metanol. Kemudian larutan ekstrak uji ditotolkan sebanyak $10 \mu \mathrm{L}$ pada lempangan KLT silika gel G 60 F254 yang berukuran $2 \times 10 \mathrm{~cm}$. Setelah penotolan lempengan KLT dielusi dalam chamber yang telah dijenuhkan sampai tanda batas. Selanjutnya plat KLT didiamkan dalam oven dengan suhu $50^{\circ} \mathrm{C}$ selama 5 menit. Selanjutnya lempengan KLT dianalisis kualitatif dengan densitometer CAMAG TLC Scanner 4. Hal yang sama dilakukan untuk masing-masing kandungan yang akan diuji.

Data puncak yang dihasilkan dari ekstrak etanol daun Anredera scandens (L.) Moq. kemudian diamati profil kromatogramnya dengan penambahan pereaksi pendeteksi yang sesuai lalu diamati di bawah sinar UV dengan panjang gelombang 200-400 nm. Untuk pereaksi pendeteksi yang digunakan serta hasil positifnya dapat dilihat pada tabel 2

Tabel 2 Pereaksi Pendeteksi Matabolit Sekunder dan Reaksi Positif yang Diberikan

\begin{tabular}{|c|c|c|}
\hline $\begin{array}{l}\text { Golongan } \\
\text { Senyawa }\end{array}$ & $\begin{array}{l}\text { Jenis Pereaksi } \\
\text { Pendeteksi }\end{array}$ & $\begin{array}{l}\text { Hasil Positif } \\
\text { Setelah Dideteksi }\end{array}$ \\
\hline Triterpenoid & $\begin{array}{l}\text { Vanilin Asam } \\
\text { Sulfat } 1 \%\end{array}$ & $\begin{array}{l}\text { Berwarna Ungu } \\
\text { setelah dipanaskan } \\
\text { pada suhu } 85- \\
90^{\circ} \mathrm{C}\end{array}$ \\
\hline Flavonoid & $\begin{array}{l}\text { Sitroborat / Uap } \\
\text { Amonia }\end{array}$ & $\begin{array}{l}\text { Berwarna kuning } \\
\text { atau berwarna } \\
\text { lembayung } \\
\text { dibawah sinar }\end{array}$ \\
\hline
\end{tabular}




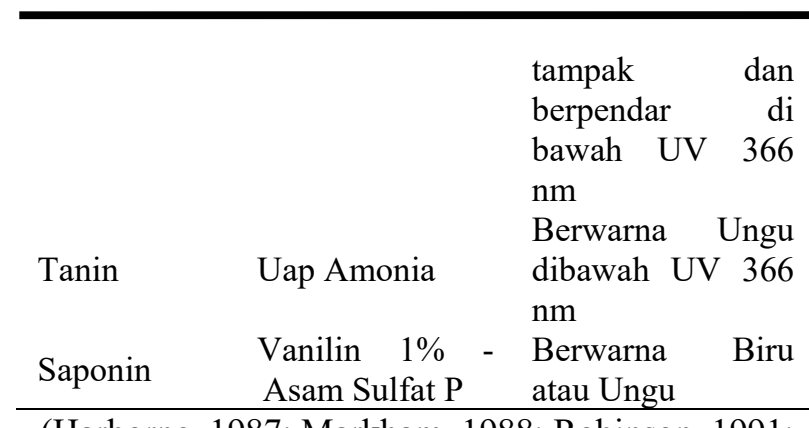

(Harborne, 1987; Markham, 1988; Robinson, 1991; Wagner and Bladt, 1996)

\subsubsection{Analisis Data}

Nilai Rf, kromatogram, dan spektrum dari tiap senyawa kimia dalam bentuk deskriptif merupakan analisis data untuk penentuan kromatografi kandungan fitokimia ekstrak etanol daun binahong (Anredera scandens (L.) Moq.).

\section{HASIL}

\subsection{Preparasi Ekstrak}

Rendemen ekstrak etanol daun binahong (Anredera scandens (L.) Moq.) yang didapat sebesar 20,75\% dengan kandungan kadar air ekstrak sebesar $8,23 \pm 0,025 \%$.

\subsection{Uji Fitokimia Ekstrak Etanol Daun} Binahong (A. scandens (L.) Moq.)

Pada ekstrak etanol daun binahong (Anredera scandens (L.) Moq.) mengandung senyawa golongan flavonoid, saponin, triterpenoid dan tanin.

\subsection{Profil Kandungan Kimia Ekstrak Etanol Daun Binahong (Anredera scandens (L.) Moq.) \\ Penentuan profil kromatografi kandungan} fitokimia dari ekstrak etanol daun binahong (Anredera scandens (L.) Moq.) dilakukan dengan metode KLT-Spektrofotodensitometri. Penentuan profil kromatogafi ini dilakukan pada senyawa flavonoid, saponin, triterpenoid dan tanin sesuai dengan hasil positif pada skrining fitokimia serta berdasarkan dari hasil identifikasi kandungan ekstrak etanol daun binahong (Anredera scandens (L.) Moq.) pada penelitian sebelumnya (Bawana, 2009; Fitria, 2009; Pratiwi, 2009; Samirana, 2010; Karismawan, 2013).

\section{PEMBAHASAN}

Penentuan profil kromatografi ekstrak etanol daun binahong (Anredera scadens (L.) Moq.) pada golongan senyawa flavonoid dilakukan dengan fase gerak Etil Asetat : Asam Asetat : Asam Formiat : Air (100:11:11:26) (Reich and Blatter, 2004). Tujuan dari penentuan profil kromatografi kandungan fitokimia ini adalah sebagai parameter standarisasi yang dapat menjamin kualitas dan kuantitas dari kandungan fitokimia ekstrak etanol daun binahong (Anredera scandens (L.) Moq.) Penampak bercak (bercak hasil elusi), densitogram dan spektrum merupakan parameter yang dapat dijadikan sebagai profil kromatogram. Hasil elusi ekstrak etanol daun binahong (Anredera scandens (L). Moq.) pada identifikasi

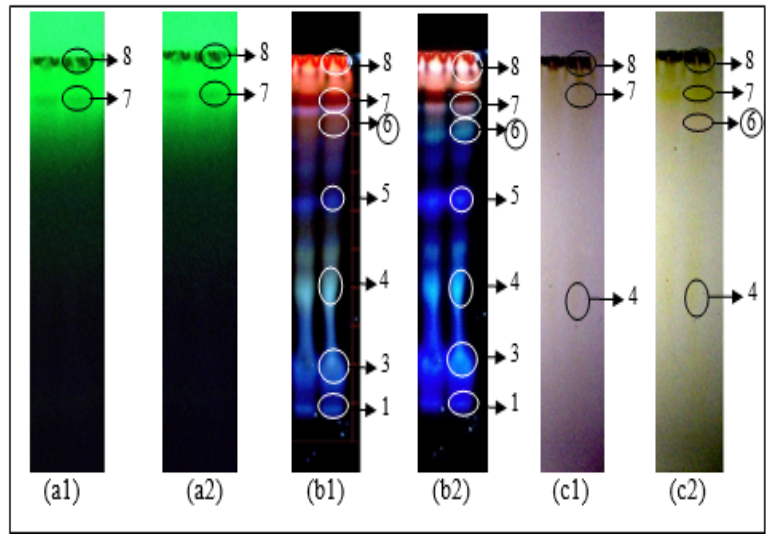

golongan senyawa flavonoid di bawah sinar uv $254 \mathrm{~nm}$, uv $366 \mathrm{~nm}$ dan pada sinar tampak dapat dilihat pada gambar 1 .

Gambar 1. Penampak Bercak (Bercak Hasil Elusi) Ekstrak Etanol Daun Binahong (Anredera scandens (L). Moq.) pada Indentifikasi Golongan Senyawa Flavonoid yang dilihat di bawah Sinar UV 254 nm (a), UV 366 nm (b) dan pada Sinar Tampak (c)

Keterangan: 1 : sebelum diuapi amonia (a1, b1, dan c1)

2 : setelah diuapi amonia (a2, b2 dan c2)

Selanjutnya plat KLT di-scan pada panjang gelombang $210 \mathrm{~nm}$. Densitogram yang diperoleh menunjukan adanya 8 bercak dapat dilihat pada gambar 2 . 


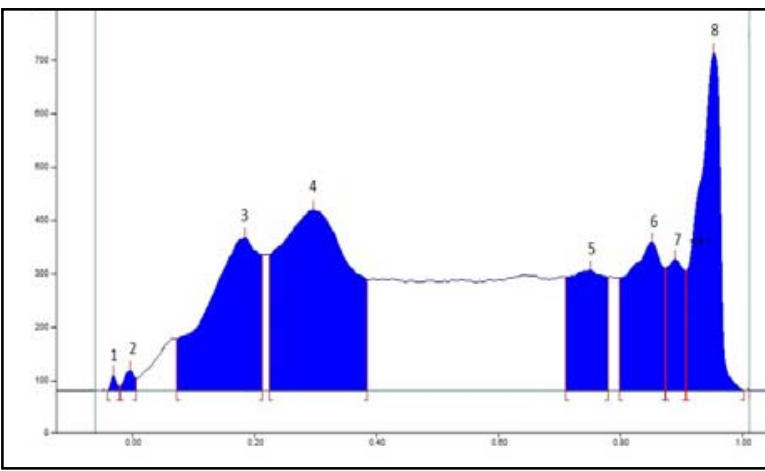

Gambar 2 Densitogram Ekstrak Etanol Daun Binahong (Anredera scandens (L). Moq.) pada Indentifikasi Golongan Senyawa Flavonoid pada Panjang Gelombang $210 \mathrm{~nm}$

Hasil pengamatan berupa data $\mathrm{Rf}$ dan warna bercak pada plat KLT dibawah sinar UV $254 \mathrm{~nm}$, UV $366 \mathrm{~nm}$ dan sinar tampak ditampilkan pada tabel 1 .

Berdasarkan data tabel 3, bercak ke-6 setelah diuapi dengan amonia menunjukkan warna merah lembayung. Selain itu, bercak ke-6 juga berflouresensi biru kehijauan dibawah sinar UV $366 \mathrm{~nm}$. Hal ini menunjukkan kemungkinan kandungan golongan senyawa flavonoid pada bercak tersebut. Berdasarkan spektrum yang dihasilkan dari bercak ke-6 setelah di-scan pada rentang panjang gelombang 200-400 $\mathrm{nm}$, bercak ke-6 memiliki spektrum khas dari golongan senyawa flavonoid dengan dua panjang gelombang maksimum yaitu pada $274 \mathrm{~nm}$ dan $340 \mathrm{~nm}$ (gambar 3 ).

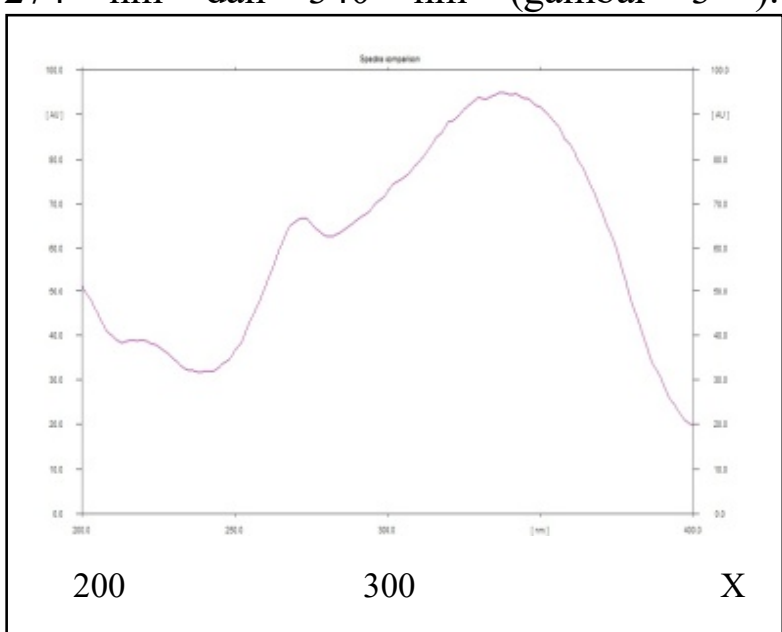

Gambar 3. Spektrum Bercak ke-6 dari Ekstrak Etanol Daun Binahong (Anredera scandens (L.) Moq.) (C)

Keterangan : $\mathrm{X}=$ panjang gelombang $(\mathrm{nm}), \mathrm{Y}=$ absorbansi (AU)

Tabel 3 Hasil Pengamatan Rf dan Warna Bercak pada Penentuan Profil Kromatografi Kandungan Fitokimia Golongan Senyawa Flavonoid

\begin{tabular}{|c|c|c|c|c|c|c|c|}
\hline \multirow[t]{3}{*}{ spot ke- } & \multirow{2}{*}{\multicolumn{2}{|c|}{ Nilai Rf }} & \multicolumn{5}{|c|}{ Pengamatan Visual } \\
\hline & & & UV 254 nm & \multicolumn{2}{|c|}{ UV 366 nm } & \multicolumn{2}{|c|}{ Sinar Tampak } \\
\hline & BV & TV & TV & BV & TV & BV & TV \\
\hline 1 & 0,00 & 0,00 & - & Biru & Biru & - & - \\
\hline 2 & 0,03 & 0,01 & - & - & - & - & - \\
\hline 3 & 0,18 & 0,18 & - & $\begin{array}{l}\text { Biru } \\
\text { muda }\end{array}$ & $\begin{array}{l}\text { Biru } \\
\text { muda }\end{array}$ & - & - \\
\hline 4 & 0,31 & 0,31 & - & $\begin{array}{l}\text { Hijau } \\
\text { muda }\end{array}$ & $\begin{array}{l}\text { Hijau } \\
\text { muda }\end{array}$ & $\begin{array}{l}\text { Kuning } \\
\text { muda }\end{array}$ & Kuning \\
\hline 5 & 0,75 & 0,75 & - & Biru & Biru & - & - \\
\hline 6 & 0,81 & 0,81 & - & $\begin{array}{l}\text { Hijau } \\
\text { muda }\end{array}$ & $\begin{array}{c}\text { Biru } \\
\text { kehijau } \\
\text { an }\end{array}$ & - & $\begin{array}{c}\text { Merah } \\
\text { Lembayung* }\end{array}$ \\
\hline 7 & 0,89 & 0,84 & $\begin{array}{c}\text { Lembayung } \\
\text { gelap }\end{array}$ & $\begin{array}{l}\text { Merah } \\
\text { kebiru } \\
\text { an }\end{array}$ & $\begin{array}{l}\text { Merah } \\
\text { Kebiru } \\
\text { an }\end{array}$ & Kuning & $\begin{array}{l}\text { Kuning } \\
\text { coklat }\end{array}$ \\
\hline 8 & 0,95 & 0,91 & $\begin{array}{c}\text { Lembayung } \\
\text { gelap }\end{array}$ & Merah & $\begin{array}{l}\text { Merah } \\
\text { muda }\end{array}$ & Coklat & Coklat \\
\hline
\end{tabular}

Keterangan : $\mathrm{BV}=$ Sebelum diuapi amonia, $\mathrm{TV}=$ Setelah diuapi amonia, $*=$ diduga mengandung senyawa golongan flavonoid 
Penentuan profil kromatografi ekstrak etanol daun binahong (Anredera scadens (L.) Moq.) untuk golongan senyawa saponin dilakukan dengan fase gerak Kloroform : Metanol : Air (70:30:4) (Reich and Blatter, 2004). Penampak bercak (bercak hasil elusi), densitogram dan spektrum merupakan parameter yang dapat dijadikan sebagai profil kromatogram. Plat KLT setelah dielusi menghasilkan beberapa bercak yang dapat

Gambar 4 Penampak Bercak (Bercak Hasil Elusi) Ekstrak Etanol Daun Binahong

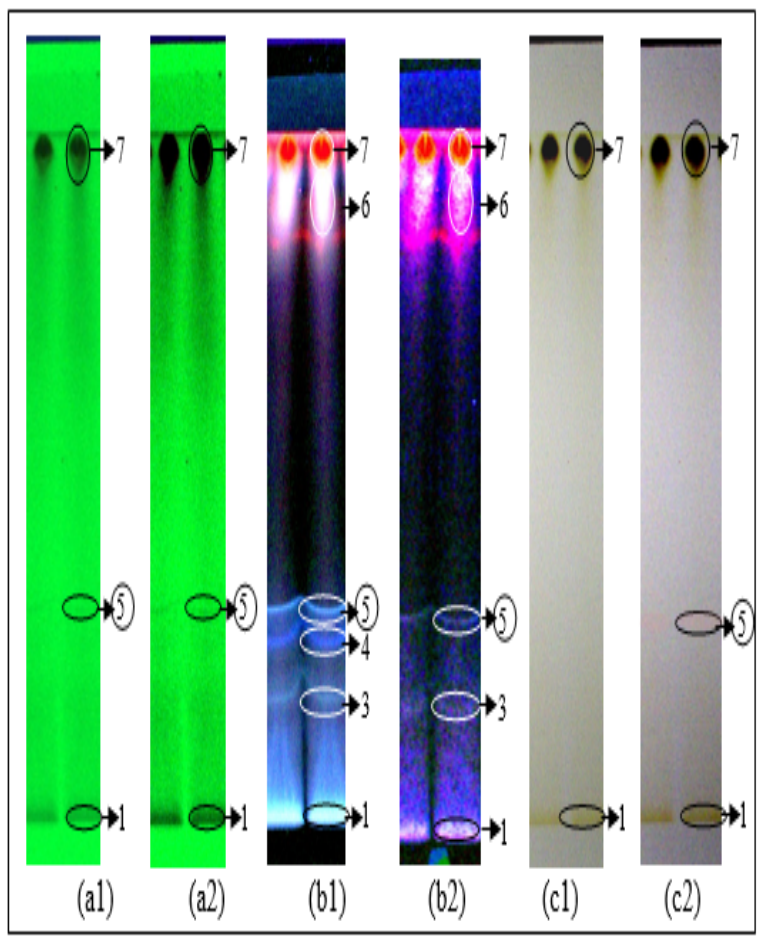

(Anredera scandens (L). Moq.) pada Indentifikasi Golongan Senyawa Saponin yang dilihat di bawah Sinar UV $254 \mathrm{~nm}$ (a), UV $366 \mathrm{~nm}$ (b) dan pada Sinar Tampak (c) diamati pada sinar UV 254 nm, sinar UV 366 $\mathrm{nm}$ dan sinar tampak yang ditunjukkan pada gambar 4.

Selanjutnya plat KLT di-scan pada panjang gelombang $206 \mathrm{~nm}$. Densitogram yang diperoleh menunjukan adanya 7 bercak seperti yang ditunjukkan pada gambar 5 .

Keterangan: 1: sebelum disemprot pereaksi vanilin $1 \%$ - Asam Sulfat P (a1, b1, dan c1)

2 : setelah disemprot pereaksi vanilin $1 \%$ - Asam Sulfat (a2, b2 dan c2)

Untuk memastikan bahwa bercak mengandung golongan senyawa saponin, maka diperlukan pereaksi pendeteksi warna yaitu disemprot dengan vanilin $1 \%$ dan asam sulfat $\mathrm{P}$. Berdasarkan data tabel 4, hanya

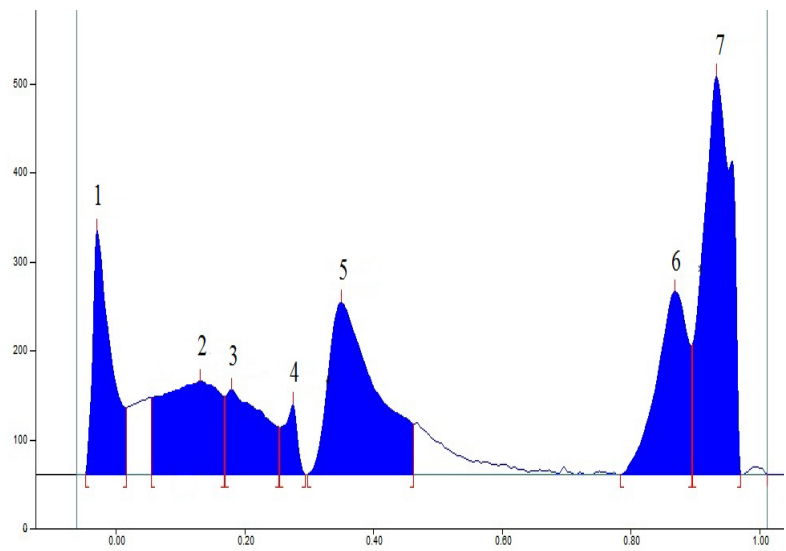

bercak ke-5 yang memberikan perubahan warna menjadi merah muda setelah disemprot dengan vanilin $1 \%$-asam sulfat $\mathrm{P}$. Hal ini menunjukkan bahwa bercak ke-5 diduga mengandung golongan senyawa saponin.

Tabel 4 Hasil Pengamatan Rf dan Warna Bercak pada Penentuan Profil Kromatografi Kandungan Fitokimia Golongan Senyawa Saponin 


\begin{tabular}{|c|c|c|c|c|c|c|c|}
\hline \multirow{3}{*}{$\begin{array}{l}\text { Spot } \\
\text { ke- }\end{array}$} & \multirow{2}{*}{\multicolumn{2}{|c|}{ Nilai Rf }} & \multicolumn{5}{|c|}{ Pengamatan Visual } \\
\hline & & & UV 254 nm & \multicolumn{2}{|c|}{ UV 366 nm } & \multicolumn{2}{|c|}{ Sinar Tampak } \\
\hline & BV & TV & BV & BV & TV & BV & TV \\
\hline 1 & 0,10 & 0,09 & $\begin{array}{c}\text { Lembayung } \\
\text { gelap }\end{array}$ & $\begin{array}{l}\text { Biru } \\
\text { muda }\end{array}$ & Ungu muda & $\begin{array}{c}\text { Coklat } \\
\text { muda }\end{array}$ & Coklat \\
\hline 2 & 0,13 & 0,12 & - & - & - & - & - \\
\hline 3 & 0,18 & 0,18 & - & Biru & Ungu & - & - \\
\hline 4 & 0,28 & 0,26 & - & Biru & - & - & - \\
\hline 5 & 0,32 & 0,32 & $\begin{array}{c}\text { Lembayung } \\
\text { gelap }\end{array}$ & Biru & Ungu & - & $\begin{array}{l}\text { Merah } \\
\text { muda* }\end{array}$ \\
\hline 6 & 0,87 & 0,83 & - & Putih & Merah muda & - & - \\
\hline 7 & 0,93 & 0,96 & $\begin{array}{c}\text { Lembayung } \\
\text { gelap }\end{array}$ & Merah & Merah & Coklat & Coklat \\
\hline
\end{tabular}

Keterangan : BV $=$ Sebelum disemprot vanillin $1 \%$-asam sulfat $\mathrm{P}, \mathrm{TV}=$ Setelah disemprot vanillin $1 \%$-asam sulfat $\mathrm{P}, *=$ diduga mengandung senyawa golongan saponin

Berdasarkan spektrum pada bercak ke-5 setelah di-scan pada rentang panjang gelombang 200-400 nm, bercak ke-5 memiliki panjang gelombang maksimum pada $206 \mathrm{~nm}$ (gambar 6). Pada penelitian ini bercak yang diduga sebagai golongan senyawa saponin yaitu bercak ke-5 dengan Rf 0,32. Hasil tersebut mendekati dengan yang dilaporkan oleh Karismawan (2013) yaitu bercak ke-4 dengan $\mathrm{Rf} 0,22$ dan yang dilaporkan oleh Samirana (2010) yaitu bercak ke-4 dengan Rf 0,18 dan bercak ke-5 dengan Rf 0,30 .

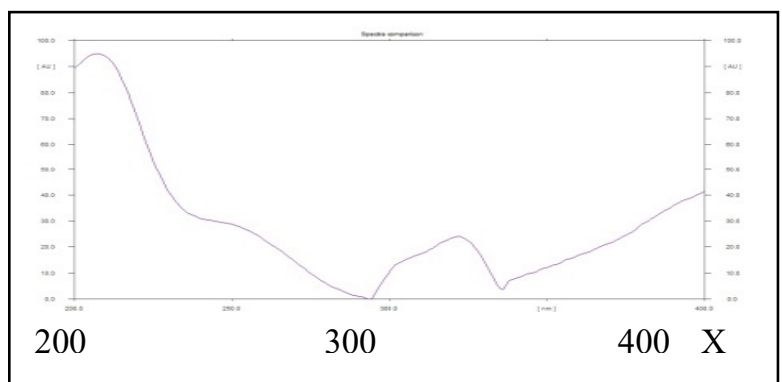

Gambar 6 Spektrum Bercak ke-5 dari Ekstrak Etanol Daun Binahong (Anredera scandens (L.) Moq.).

Keterangan : $\mathrm{X}=$ panjang gelombang $(\mathrm{nm}), \mathrm{Y}=$ absorbansi (AU)
Penentuan profil kromatografi ekstrak etanol daun binahong (Anredera scadens (L.) Moq.) untuk golongan senyawa triterpenoid dilakukan dengan fase gerak Kloroform : Metanol (10:1) (Reich and Blatter, 2004). Penampak bercak (bercak hasil elusi), densitogram dan spektrum merupakan parameter yang dapat dijadikan sebagai profil kromatogram. Densitogram yang diperoleh menunjukan adanya 9 bercak seperti yang ditunjukkan pada gambar 7 .

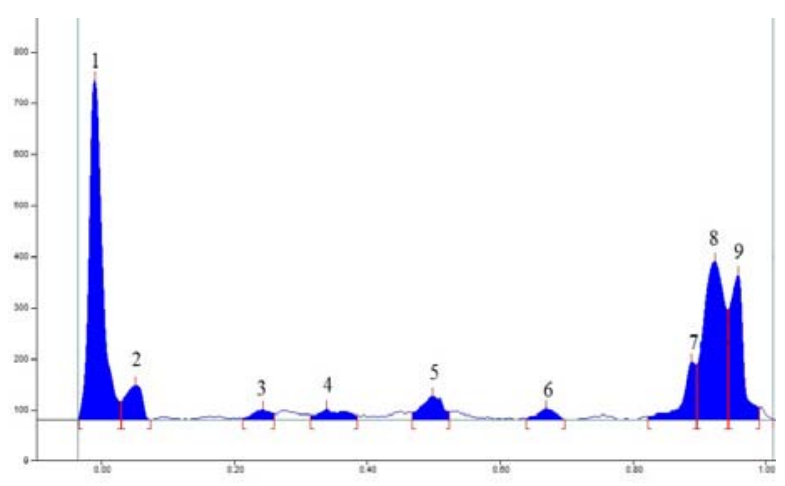

Gambar 7 Densitogram Ekstrak Etanol Daun Binahong (Anredera scandens (L). Moq.) Golongan Senyawa Triterpenoid pada Panjang Gelombang $210 \mathrm{~nm}$. 
Penampak bercak (bercak hasil elusi), densitogram dan spektrum merupakan parameter yang dapat dijadikan sebagai profil kromatogram. Plat KLT setelah dielusi menghasilkan beberapa bercak yang dapat diamati dibawah sinar UV $254 \mathrm{~nm}$ dan sinar UV $366 \mathrm{~nm}$ serta pada sinar tampak yang ditunjukkan pada gambar 8 .
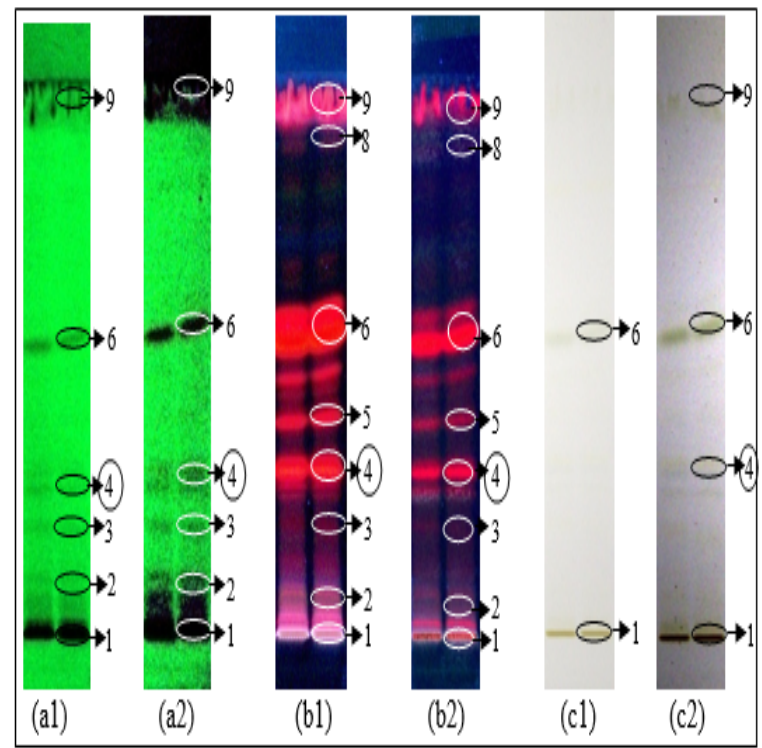

(cl)
Gambar 8

Tabel 5

Hasil Pengamatan Rf dan Warna Bercak pada Penentuan Profil Kromatografi Kandungan Fitokimia Golongan Triterpenoid

\begin{tabular}{|c|c|c|c|c|c|c|c|}
\hline \multirow{3}{*}{$\begin{array}{c}\text { Bercak } \\
\text { ke- }\end{array}$} & \multirow{2}{*}{\multicolumn{2}{|c|}{ Nilai Rf }} & \multicolumn{5}{|c|}{ Pengamatan Visual } \\
\hline & & & UV 254 nm & \multicolumn{2}{|c|}{ UV $366 \mathrm{~nm}$} & \multicolumn{2}{|c|}{ Sinar Tampak } \\
\hline & BV & TV & $\begin{array}{ll}\text { BV } & \text { TV } \\
\end{array}$ & BV & TV & BV & TV \\
\hline 1 & 0,00 & 0,00 & Lembayung gelap & $\begin{array}{l}\text { Merah } \\
\text { muda }\end{array}$ & $\begin{array}{c}\text { Merah } \\
\text { keunguan }\end{array}$ & $\begin{array}{l}\text { Coklat } \\
\text { muda }\end{array}$ & Coklat \\
\hline 2 & 0,05 & 0,04 & Lembayung & Ungu & Ungu & - & - \\
\hline 3 & 0,24 & 0,34 & Lembayung & $\begin{array}{l}\text { Merah } \\
\text { muda }\end{array}$ & Ungu & - & - \\
\hline 4 & 0,38 & 0,38 & Lembayung & Merah & $\begin{array}{c}\text { Merah } \\
\text { keunguan }\end{array}$ & - & Ungu* \\
\hline 5 & 0,51 & 0,50 & - & Merah & Merah & - & - \\
\hline 6 & 0,68 & 0,68 & Lembayung gelap & Merah & Merah & $\begin{array}{l}\text { Coklat } \\
\text { muda }\end{array}$ & Hijau \\
\hline 7 & 0,82 & 0,81 & - & - & - & - & - \\
\hline 8 & 0,92 & 0,92 & - & $\begin{array}{l}\text { Merah } \\
\text { muda }\end{array}$ & Ungu & - & - \\
\hline 9 & 0,95 & 0,96 & Lembayung gelap & Merah & $\begin{array}{c}\text { Merah } \\
\text { keunguan }\end{array}$ & - & Coklat muda \\
\hline
\end{tabular}

Keterangan : BV= Sebelum disemprot vanillin 1\%-asam sulfat $\mathrm{P}, \mathrm{TV}=$ Setelah disemprot vanillin $1 \%$-asam sulfat $\mathrm{P}, *=$ diduga mengandung senyawa golongan triterpenoid

Berdasarkan spektrum pada bercak ke-4 setelah di-scan pada rentang panjang gelombang 200-400 nm, bercak ke-4 memiliki panjang gelombang maksimum pada $210 \mathrm{~nm}$ (gambar 9). $\mathrm{nm}$. 


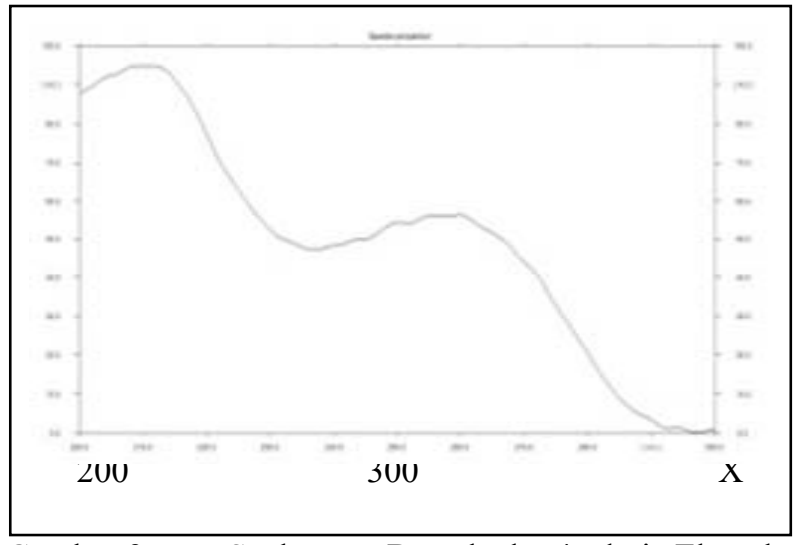

Gambar 9 Spektrum Bercak ke-4 dari Ekstrak Etanol Daun Binahong (Anredera scandens (L.) Moq.).

Keterangan : $\mathrm{X}=$ panjang gelombang $(\mathrm{nm}), \mathrm{Y}=$ absorbansi (AU

Penentuan profil kromatografi ekstrak etanol daun binahong (Anredera scadens (L.) Moq.) untuk golongan senyawa tanin dilakukan dengan fase gerak Toluen : Etil Asetat (98:2) (Reich and Blatter, 2004). Penampak bercak (bercak hasil elusi), densitogram dan spektrum merupakan parameter yang dapat dijadikan sebagai profil kromatogram. Densitogram yang diperoleh menunjukan adanya 9 bercak seperti yang ditunjukkan pada gambar 10.

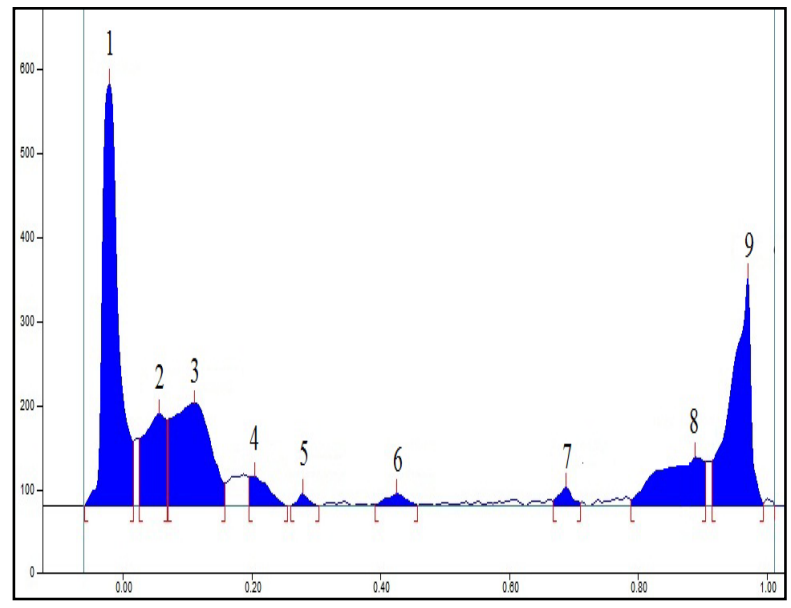

Gambar 10 Densitogram Ekstrak Etanol Daun Binahong (Anredera scandens (L). Moq.) pada Indentifikasi Golongan Senyawa Tanin.dari Penelitian ini pada Panjang Gelombang $280 \mathrm{~nm}$.
Jika dilihat berdasarkan densitogram dari hasil identifikasi golongan senyawa tanin ini memiliki pola yang hampir sama. Bercak yang diduga sebagai golongan senyawa tanin adalah bercak ke-4 dengan Rf 0,19

Penampak bercak (bercak hasil elusi), densitogram dan spektrum merupakan parameter yang dapat dijadikan sebagai profil kromatogram. Plat KLT setelah dielusi menghasilkan beberapa bercak yang dapat diamati pada sinar UV 254 nm, sinar UV 366 $\mathrm{nm}$ dan sinar tampak yang ditunjukkan pada gambar 11.

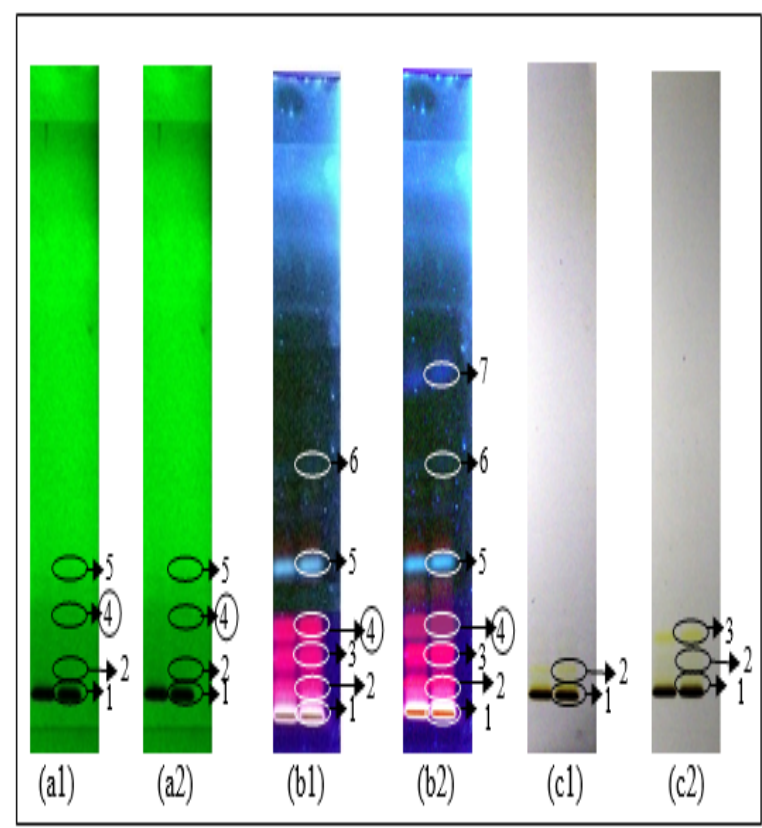

Gambar 11 Penampak Bercak (Bercak Hasil Elusi) Ekstrak Etanol Daun Binahong (Anredera scandens (L). Moq.) pada Indentifikasi Golongan Senyawa Tanin yang dilihat di bawah Sinar UV 254 nm (a), UV 366 nm (b) dan pada Sinar Tampak (c)

Keterangan: 1: sebelum diuapi amonia (a1, b1, dan c1)

2 : setelah diuapi amonia (a2, b2 dan c2)

Berdasarkan spektrum yang dihasilkan dari bercak ke-4 setelah di-scan pada rentang panjang gelombang 200-400 nm, bercak ke-4 memiliki panjang gelombang maksimum pada $250 \mathrm{~nm}$ (gambar 12). Faktor geografis dan waktu pemanenan yang berbeda 
mempengaruhi kualitas dari kandungan kimia tanaman.

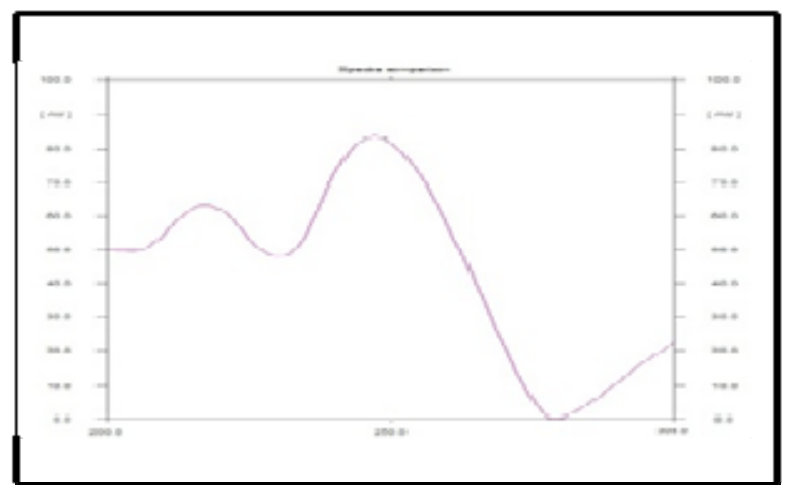

Gambar 12

Spektrum Bercak ke-4 dari Ekstrak Etanol Daun Binahong (Anredera scandens (L.) Moq.) (C).

Keterangan : $\mathrm{X}=$ panjang gelombang (nm), $\mathrm{Y}=$ absorbansi (AU)

Selanjutnya plat KLT di-scan pada panjang gelombang $280 \mathrm{~nm}$ untuk melihat adanya bercak senyawa yang mampu dipisahkan oleh fase gerak yang digunakan. Hasil pengamatan berupa data Rf dan warna bercak pada plat KLT dibawah sinar UV 254 $\mathrm{nm}$ dan UV $366 \mathrm{~nm}$ serta pada sinar tampak ditampilkan pada tabel 6 .

Tabel 6

Hasil Pengamatan Rf dan Warna Bercak pada Penentuan Profil Kromatografi Kandungan Fitokimia Golongan Tanin

\begin{tabular}{|c|c|c|c|c|c|c|c|}
\hline \multirow{3}{*}{$\begin{array}{c}\text { Bercak } \\
\text { ke- }\end{array}$} & \multirow{2}{*}{\multicolumn{2}{|c|}{ Nilai Rf }} & \multicolumn{5}{|c|}{ Pengamatan Visual } \\
\hline & & & UV 254 nm & \multicolumn{2}{|c|}{ UV $366 \mathrm{~nm}$} & \multicolumn{2}{|c|}{ Sinar Tampak } \\
\hline & BV & TV & $\begin{array}{ll}\text { BV } & \text { TV }\end{array}$ & BV & TV & BV & TV \\
\hline 1 & 0.00 & 0.00 & Lembayung gelap & $\begin{array}{l}\text { Merah } \\
\text { muda }\end{array}$ & Merah muda & Coklat & Coklat \\
\hline 2 & 0.06 & 0.06 & Lembayung & Merah & Merah & Kuning & Kuning \\
\hline 3 & 0.12 & 0.12 & - & Merah & Merah & - & Kuning \\
\hline 4 & 0.19 & 0.19 & Lembayung & Merah & $\begin{array}{c}\text { Ungu } \\
\text { Kemerahan* }\end{array}$ & - & - \\
\hline 5 & 0.28 & 0.25 & Lembayung & $\begin{array}{l}\text { Biru } \\
\text { Muda }\end{array}$ & Biru & - & - \\
\hline 6 & 0.43 & 0.44 & - & $\mathrm{Abu}$ & $\mathrm{Abu}$ & - & - \\
\hline 7 & 0.69 & 0.69 & - & - & Biru & - & - \\
\hline 8 & 0.85 & 0.88 & - & - & - & - & - \\
\hline 9 & 0.97 & 0.95 & - & - & - & - & - \\
\hline
\end{tabular}

Keterangan : $\mathrm{BV}=$ Sebelum diuapi amonia, $\mathrm{TV}=$ Setelah diuapi amonia, $*=$ diduga mengandung senyawa golongan $\operatorname{tanin}$

\section{KESIMPULAN}

Profil kromatografi kandungan fitokimia dari ekstrak etanol daun binahong (Anredera scandens (L.) Moq.) dengan fase gerak etil asetat: asam asetat: asam formiat: air (100:11:11:26) menunjukkan pada bercak ke6 (Rf 0,81) dengan $\lambda$ maks $340 \mathrm{~nm}$ yang berwarna merah lembayung setelah dideteksi dengan uap ammonia diduga golongan senyawa flavonoid; pada fase gerak kloroform: metanol: air (70:30:4) menunjukan pada bercak ke-5 (Rf 0,32) dengan $\lambda_{\text {maks }} 206$ $\mathrm{nm}$ yang berwarna merah muda setelah dideteksi dengan pereaksi vanilin 1\%-asam sulfat diduga golongan senyawa saponin; pada fase gerak kloroform: metanol (10:1) menunjukkan pada bercak ke-4 (Rf 0,38) dengan $\lambda_{\text {maks }} 210 \mathrm{~nm}$ yang berwarna ungu setelah dideteksi dengan pereaksi vanilin asam sulfat $1 \%$ dan dipanaskan pada suhu $90^{\circ} \mathrm{C}$ diduga golongan senyawa triterpen; pada fase gerak etil asetat: toluen (2:98) menunjukkan pada bercak ke-4 (Rf 0,19) dengan $\lambda_{\text {maks }} 250 \mathrm{~nm}$ yang berwarna ungu kemerahan di bawah sinar UV $366 \mathrm{~nm}$ setelah diberikan uap amonia diduga golongan senyawa tanin.

\section{UCAPAN TERIMA KASIH}

Penulis mengucapkan terima kasih kepada semua rekan-rekan serta pihak yang telah membantu dan memberi saran pada penelitian ini. 


\section{DAFTAR PUSTAKA}

Bawana, I. B. A. 2009. Uji Aktivitas Antibakteri Ekstrak Daun Binahong Anredera scandens (L.) Moq. yang Dikoleksi dari Berbagai Tempat di Bali (Skripsi). Denpasar: Universitas Udayana. Hal. 33.

Ciulei, J. 1984. Metodology for Analysis of Vegetables and Drugs. Bucharest Rumania: Faculty of Pharmacy. Page: 11-26.

Depkes RI. 1995. Materia Medika Indonesia Jilid VI. Jakarta: Departemen Kesehatan Republik Indonesia. Hal. 333-337.

Dewi, I.D.A.D.Y., K.W. Astuti dan N.K. Warditiani. 2013. Identifikasi Kandungan Kimia Ekstrak Kulit Buah Manggis (Garcinia mangostana L.). Jurnal Farmasi Udayana. 2(4): 13-18

Feybriyanti, Y. W. 2011. Uji Aktivitas Antiinflamasi Ekstrak N-Heksan, Kloroform, dan Etanol Daun Binahong (Anredera scandens (L.) Moq.) pada Tikus yang Diinduksi Karagenan 1\% (Skripsi). Denpasar: Universitas Udayana.

Fitria, A. 2009. Uji Aktivitas Antibakteri Ekstrak Daun Anredera cordifolia (Ten.) Steen, Anredera scandens (L.) Moq., Basella rubra L. pada Bakteri Gram Positif dan Bakteri Negatif (Skripsi). Denpasar: Universitas Udayana.

Gandjar, I. G. dan A. Rohman. 2007. Kimia Analisis Farmasi. Yogyakarta : Pustaka Pelajar. hal 46-49.

Harborne, J.B. 1987. Metode Fitokimia: Penuntun Cara Modern Menganalisis Tumbuhan. Terbitan Kedua. Bandung: Penerbit ITB. Hal. 127.
Karismawan, P. N. 2013. Profil Kandungan Kimia dan Uji Aktivitas Antiluka Bakar Ekstrak Etanol Daun Binahong (Anredera Scandens (L.) Moq.) Pada Tikus Jantan Galur Sprague Dawley (Skripsi). Denpasar: Universitas Udayana.

Manoi, F. 2009. Binahong sebagai Obat. Warta Penelitian dan Pengembangan Tanaman Industri, Vol. 15(1): 3-4.

Markham, K.R. 1988. Cara Mengidentifikasi Flavonoid. Bandung: Penerbit ITB. Hal. 25-26.

Pratiwi, N. L. P. D. H. 2009. Uji Aktibakteri Ekstrak Daun Tua dan Daun Muda dari Tanaman Binahong (Anredera scandens (L.) Moq.) terhadap Bakteri Gram Positif dan Gram Negatif. (Skripsi). Denpasar: Universitas Udayana. Hal. 32.

Reich, E. and A. Blatter. 2004. Modern TLC A Key Technique of Identification and Quality Control of Botanical and Dietary Supplements. Journal Association of Official Analytical Chemists International. Page: 16-17.

Robinson, T. 1991. Kandungan Organik Tumbuhan Tingkat Tinggi. Bandung: Penerbit ITB. Hal. 152-196.

Samirana, P. O., N. P. E. Leliqia, and N. P. Ariantari. 2014. TLC-Densitometer Profile and Antiulcer Activity Assay of Ethanol Extract of Binahong Leaves (Anredera Scandens (L.) Moq.) in Sprague Dawley Strain Male Rats. Proceeding The International Conference of Pharmaceutical Care. Pp. 63-71

Wagner, H. and S. Bladt. 1996. Plant Drugs Analysis A Thin Layer Chromatography Atlas. 2nd Edition. Germany: Springer Verlag Berlin Heidelberg. P. 195-244. 
JUNAL FARMASI UDAYANA

Vol. 6 No 1 Tahun 2017

ISSN 2301-7716 